\title{
Decision Making and Job Satisfaction as Correlates of Teachers' Job Performance in Junior Secondary Schools in Abia State, Nigeria
}

\author{
Uba-Mbibi, Felicia Oluchi \\ Department of Agricultural/Home Economics Education \\ Michael Okpara University of Agriculture, Umudike, Abia State, Nigeria
}

\section{Doi:10.5901/mjss.2013.v4n8p107}

\begin{abstract}
This study specifically sought to determine decision making and job satisfaction as correlates of teachers' job performance in junior secondary schools in Abia state, Nigeria. Two research questions were posed and two null hypotheses formulated to guide the investigation, which was carried out ex-post factor, using a descriptive survey design. A sample of 541 junior secondary schools was drawn from a population of 1082 in the 230 junior secondary schools in Abia state. Data were collected using the researcher's self constructed questionnaire from the respondents titled involvement of teachers in decision making and job satisfaction as correlates of teachers' job performance in junior secondary schools (ITDMJSTJPQ). To ensure face validity of the instrument, two experts in Educational Administration and Planning of Abia State College of Education were consulted. There expert comments were used to modify the final copy of the questionnaire used for the study. Data were analyzed using frequency distribution, ad mean rating to answer the two research questions posted while the Z-test statistic was used to test the null hypotheses formulated. Results indicated that although the teachers were involved in decision making but some decisions reached were not implemented by the school principals. As a result of this, there was lack of job satisfaction and low job performance among junior secondary school teachers in the junior secondary schools. The test of hypothesis one shows that there was no significant difference between teachers' decision making and job performance. Based on the findings, it was recommended that principals should involve and implement teachers' decisions in schools to enhance their job performance for uplifting of educational standard in Nigeria.
\end{abstract}

\section{Introduction}

Teachers' job performance in Nigeria has become an issue of public concern. This is because of declining standard of junior secondary schools in Abia State. Students no longer perform creditably in examination especially in junior school certificates (JSCE) as noted by parents, and guardians. Plank (2011) remarked that some secondary school products are deficient in learning and in character and their performance in school certificate examination in Nigeria is unimpressive. Nwadiani cited in Okunamiri and Uba-Mbibi (2011) stated that the poor quality is reflected in the very low productivities and job performance of secondary school leaver in the world of work.

Education is very essential in fostering economic growth and national development. Hence the Federal Republic of Nigeria (2004) states that education is the most important instrument of change. It is apparently through teaching and learning that the change is achieved in any nation through a teacher. The teacher is an important factor of development and he exerts tremendous influence in interpreting and implementing school curriculum, which is the essence of education. Therefore, it is not surprising that Abraham (2012) stressed that the teacher factor is one major input that should never be compromised. Academic excellence which entails the inculcation of the right type of knowledge, skill, values and attitudes to the learners to enable them function efficiently and effectively within the society can mainly be achieved through disciplined and committed teachers. 
Involvement of teachers in decision making is very imperative as they are the life wire of teaching and learning in secondary schools. Unimplemented decisions are very irritating and may lead to lack of teachers' job satisfaction. It is therefore very important to determine whether teachers are involved in decision making and if decisions reached are adequately implemented Butter (2012) noted that teachers are being marginalized when compared with those in other professions when it comes to decision making. It appears that teachers are not involved in decision making or their decisions are not adequately implemented hence they are not satisfied with their jobs. Mark (2011) has noted that principals take decisions all alone without involving the teachers. Perry (2011) remarked that decision making is the process of choosing from two or more options that best suit a particular situation requiring altered action. Tanfox (2010) is of the view that starting with the teacher can approach the curriculum improvement function of supervisor of a school, it is surprising that these wonderful teachers are mere technicians who only need to heed to the construction of programmed materials, and professional decisions are made without involving the teachers who carry out the implementation. The consequence is poor performance of the teachers and observable falling standard of education in the system. It appears that teachers are not involved in decision making in their schools. Ako (2013) opined that lack of involvement of teachers in decision making leads to resistance of orders and poor performance of teachers. Ako also noted that teachers are not involved in decision making in the area of the study.

There is a lot of tension and conflicts in secondary schools today possibly as a result of lack of involvement of teachers in decision making in schools or those who would help to implement the decisions are not given any thought. Agbai cited in Okunamiri and Uba-Mbibi (2011) highlights that; the problem with Nigerian educational system is not on decision making formulation but in the implementation of decisions. According to Perry (2011) there are cases of school principals either taking decisions alone or handpicking teachers whom they consider as their favorites to assist them in taking decisions. This invariably means that involving teachers in matters concerning teachers' matters (welfare) are not encouraged.

This study therefore underscored the seeming inability of the secondary school administrators to involve teachers in decision making in school meetings. The purpose of this study therefore, is to examine the influence of teacher's participation in decision making and job performance in secondary schools in Abia State, Nigeria.

\section{Statement of the Problem}

There have been serious complaints by well meaning Nigerians on the declining performance of teachers in junior secondary schools in Abia State. This is as a result of declining standard of education in the secondary school system. Research literature confirms the declining dedication of teachers to their duties. It has been alleged by some well meaning Nigerians that teachers in Abia State are not satisfied with their job. The situation is worst as the principals could not involve teachers in decision making in their schools. There is therefore a need for a study of involvement of teacher in decision making in schools to minimize job dissatisfaction among teachers. The problem of this study therefore derives from inability of school principals to involve teachers in decision-making in schools.

This study therefore sought to determine whether teachers are involved in decision making in secondary schools in Abia State and what job satisfaction variable shat would enhance their performance so as to improve the declining standard of quality of secondary education in Abia State, Nigeria.

\section{Purpose of the Study}

The purpose of the study is to investigate decision-making and job satisfaction as correlates of teachers, job performance in junior secondary schools in Abia State. Specifically the objectives of the study are to find out:

i. Whether teaches' participation in decision making as a motivational factor will enhance teachers' 
performance.

ii. If implementation of teachers' decisions in schools as job satisfaction variable constitutes a correlate of teachers' job performance in the area of the study?

\section{Research Question and Hypotheses}

To guide the investigation, two research questions were posed while two hypotheses were formulated and tested at 0.05 significance level.

\subsection{Research Questions:}

1. Does involvement of junior secondary school teachers in decision making in schools as job satisfaction variable constitute a correlate of teachers' job performance in the area of the study?

2. To what extent does implementation of teachers' decision in schools and job satisfaction variable correlate with teachers' job performance in the area of the study?

\subsection{Hypotheses}

- Ho1: There is no significant difference in the mean ratings of teachers' responses on the extent to which teachers' participation in decisions-making serve as a correlate of teachers' job performance in junior secondary schools in Abia state.

- $\mathrm{H}_{2}$ : There is no significant difference in the mean ratings of teachers' responses on the extent to which implementation of teachers' decisions serve as a correlate of teachers' job performance in junior secondary schools in the area of the study.

\subsection{Methodology}

The design used for the study was a descriptive survey carried out ex-post-facto. The population comprised all the teachers in the junior secondary schools in the three education zones of Abia State, Nigeria. The teachers' population was stratified according to three educational zones as follows: Aba, Umuahia, and Ohafia. And from each education zone, fifty percent (50\%) of the teachers' population - (1082) was used for the study. This gave a sample of 541 junior secondary school teachers. This was used as a Sample for the study.

The instrument used for the study was the researchers' self constructed questionnaire titled DecisionMaking and Job Satisfaction as correlates of teachers' job performance in junior secondary schools Questionnaire (DMJSTPQ) which consisted of sections A and B. Section A sought information on the bio data of the respondents, while section $B$ elicited information on involvement of teachers in decision making and job satisfaction in junior secondary schools in Abia State. The level of agreement and disagreement with the items in the questionnaire were administered to the respondents who provided their opinions by ticking $(\sqrt{ })$ the rating scale which was patterned in line with the four point likert scale namely Strongly Agree (SA), Agree (A), Disagree (D), and Strong Disagree (SD). To ensure face validity of the instrument, two experts in Educational Administration and Planning of Abia State College of Education were consulted. There expert comments were used to modify the final copy of the questionnaire used for the study.

The reliability of the instrument was determined by test-retest method. By this method, a trail test was carried out using (30) Junior Secondary School Principals in the three (3) education Zones of Abia State who were not part of the sample. The exercise was repeated after two weeks interval on the same respondents. The two sets of texts were computed statistically using Person product Moment Correlation Statistics. The instrument was found to have a reliability coefficient level of 0.91 , which was considered high enough and 
therefore adequate for the study.

Five hundred and forty one (541) copies of the questionnaire were distributed to the principals and all were duly completed and returned. This gave $100 \%$ returned of the questionnaire by the principals. The two research questions were answered using frequency distributions, and mean rating while the hypotheses were tested using z-test.

\section{Results}

\subsection{Research Question One}

Do teachers' participation in decision making enhance their performance at school?

Table 1: Mean Rating Of Teachers' Participation in Decision Making to Enhance Their Performance in Junior Secondary Schools in Abia State.

\begin{tabular}{|c|c|c|c|c|c|c|c|c|c|}
\hline$S / N$ & Items & $\begin{array}{l}\text { SA } \\
(4)\end{array}$ & $\begin{array}{c}\text { A } \\
(3)\end{array}$ & $\begin{array}{l}D \\
(2)\end{array}$ & $\begin{array}{l}\text { SD } \\
(1)\end{array}$ & $\begin{array}{l}\text { Total } \\
\text { Score }\end{array}$ & $\begin{array}{l}\text { Mean } \\
\text { Score }\end{array}$ & Decision & $\begin{array}{l}\text { Pooled } \\
\text { Mean }\end{array}$ \\
\hline 1 & $\begin{array}{l}\text { Teachers' are involved in decision making in } \\
\text { my school. }\end{array}$ & 400 & 435 & 250 & 280 & 1265 & 2.73 & Positive & \multirow{5}{*}{2.54} \\
\hline 2 & $\begin{array}{l}\text { Teachers' involvement in decision making in } \\
\text { my school boosts their morale. }\end{array}$ & 290 & 270 & 400 & 280 & 1220 & 2.44 & Negative & \\
\hline 3 & $\begin{array}{l}\text { Teachers have comfortable venue for } \\
\text { meetings in my schools. }\end{array}$ & 400 & 180 & 330 & 245 & 1125 & 2.30 & Negetive & \\
\hline 4 & $\begin{array}{l}\text { Teachers' involvement in decision making in } \\
\text { my school enhances their cooperation with the } \\
\text { school regulations. }\end{array}$ & 380 & 400 & 310 & 300 & 1390 & 2.78 & Positive & \\
\hline 5 & $\begin{array}{l}\text { Teachers always have conflicts during } \\
\text { meetings. }\end{array}$ & 380 & 390 & 220 & 240 & 1230 & 2.46 & Negative & \\
\hline
\end{tabular}

With the exception of 2 items Nos. (1) and (4) and the pooled mean (2.54) respectively the mean scores of the other 3 items of the five (5) items are non-motivational ((2.44), (2.30) and (2.46). That means that teachers are participating adequately in decision making in their schools to enhance their performance.

\subsection{Research Question 2}

Table 2: The Mean Ratings of Implementation of Teachers' Decisions in Schools in the Area of the Study.

\begin{tabular}{|c|c|c|c|c|c|c|c|c|c|}
\hline $\mathrm{S} / \mathrm{N}$ & Items & $\begin{array}{l}\text { SA } \\
(4)\end{array}$ & $\begin{array}{l}\text { A } \\
(3)\end{array}$ & $\begin{array}{l}D \\
(2)\end{array}$ & $\begin{array}{l}\text { SD } \\
(1)\end{array}$ & $\sum X$ & $\begin{array}{l}\text { Mean } \\
\text { Score }\end{array}$ & Decision & $\begin{array}{l}\text { Pooled } \\
\text { Mean }\end{array}$ \\
\hline 6 & Teachers like to attend school meetings. & 400 & 450 & 345 & 120 & 1315 & 2.63 & Positive & \multirow{5}{*}{2.37} \\
\hline 7 & $\begin{array}{l}\text { Implementation of decisions in my schools } \\
\text { enhances teachers' performance. }\end{array}$ & 80 & 400 & 240 & 200 & 1040 & 2.08 & Negative & \\
\hline 8 & $\begin{array}{l}\text { Teachers in my school implement principals' } \\
\text { decision adequately in my school. }\end{array}$ & 240 & 270 & 320 & 190 & 1020 & 2.04 & Negative & \\
\hline 9 & $\begin{array}{l}\text { Implementation of teachers' decisions enhances } \\
\text { their cooperation in my school. }\end{array}$ & 160 & 300 & 340 & 230 & 1030 & 2.06 & Negative & \\
\hline 10 & $\begin{array}{l}\text { Implementation of teachers' decision boosts } \\
\text { their morale in my school. }\end{array}$ & 200 & 270 & 490 & 130 & 1090 & 2.18 & Negative & \\
\hline
\end{tabular}

As shown in the table 2 above, the mean rating responses of the teachers in no 1 out of the 5 items is 
positive (2.63), while the means of the other four items and the polled mean are negative (2.37). It implies that implementation of decisions of the teachers reached in meetings is not adequately implemented to serve as motivational variable to enhance teachers' performance in junior secondary schools in the area of the study, although, teachers attend meetings and contribute meaningfully.

\subsection{Hypothesis One $(\mathrm{HO})$}

There is no significant difference in the mean ratings of teachers' responses on the extent to which teachers' participation in decision-making as job satisfaction variable serve as a correlate with teachers' job performance.

Table 3: Z-Test Statistic Analysis of Participatory Decisions Making and Teachers' Job Performance

\begin{tabular}{|c|c|c|c|c|c|c|}
\hline Respondents & $\mathrm{N}$ & $\mathrm{X}$ & $\mathrm{Sd}$ & Standard Error Estimate & Z-Cal. & Z-Critical \\
\hline Agree & \multirow{2}{*}{541} & 413.6 & 20.48 & 12.98 & 1.96 & 1.96 \\
\cline { 3 - 7 } & 147.4 & 33.46 & & & \\
\hline Disagree & & & & & \\
\hline
\end{tabular}

Table 3 indicates that Z-test critical value of 12.98 is greater than the Z-test calculated value of 1.96 . This shows that the null hypothesis is rejected. Thus, there is no significant difference in the mean ratings of teachers' responses on the extent to which teachers' involvement in decision making serves as correlate of teacher' job performance,

\subsection{Hypothesis two $\left(\mathrm{Ho}_{2}\right)$}

Table 4: Z-Test Statistic Analysis of Implementation of Teachers' Decisions and Teachers' Job Performance.

\begin{tabular}{|c|c|c|c|c|c|c|}
\hline Respondents & $\mathrm{N}$ & $\mathrm{X}$ & $\mathrm{Sd}$ & Standard Error Estimate & Z-Cal. & Z-Critical \\
\hline Agree & \multirow{2}{*}{541} & 282.4 & 164.80 & 101.10 & 0.12 & 1.96 \\
\cline { 4 - 7 } & & 294.6 & 154.74 & & & \\
\hline Disagree & & & & \\
\hline
\end{tabular}

Result on table 4 indicates that the Z-test Value of 1.96 is greater than the Z-test Critical Value of 0.12 . This implies that the null hypothesis is accepted. Therefore, there is no significant difference in the mean rating of teachers' responses on the extent to which implementation of decisions constitute a correlate of teachers' job performance.

\section{Discussions}

Research question 1 examined the extent to which the involvement of junior secondary teachers in the three education zones in Abia State enhances teachers' performance. The answers to research question (1) was obtained using the 5 items (1-10) cluster of questions which were completed by the teachers. The result data analyzed as shown in table 1, showed that the teachers' participation in decision-making in secondary schools did not serve as motivational variable in Umuahia Education Zone of Abia State. The pooled means of the 5 item cluster of the questions (Nos. $1-5$ ) is 2.54. Since it is positive and above the range/bench mark of 2.50, that means that teachers were adequately involved in decision making in junior secondary schools in Abia State Education zone. This is in line with Agbai (2009) who argues that the problem with Nigerian educational system is not on decision making formulation but in the implementation of decisions.

As regards research question 2 which sought information on the extent of implementation of teachers decisions on their performance in the schools in the area of the study, the result of the data analysis were got with 5 item questions (Nos. 6 -10) is represented in table 2 above. The data indicated that the decisions of the teachers were not adequately utilized in junior secondary schools in Abia State with the pooled mean of 
2.37. This is below the bench mark of 2.50 that implies that the decisions of the teachers were not adequately implemented and therefore did not serve as motivational variable on the teachers' performance at schools.

$\mathrm{Ho}_{1}$ : There is no significant difference in the mean ratings of teachers' responses on the extent to which teachers' participation in decisions-making serve as a correlate of teachers' job performance in junior secondary schools in Abia State. The result of this data based on the hypothesis is presented in table 3. The mean rating scores shows that there is a significant difference in the mean rating responses of teachers on the extent to which teachers' participation in decisions-making serve as a correlate of teachers' job performance. This implies that the null hypothesis is thereof rejected. The result of the study proved Ako (2013) otherwise who stated that teachers are not involved in decision making in schools in Abia State. In effect, teachers are involved in decision making and servers as motivational variable although, did not enhance their performance as students are lacking both in character and in learning as noted by Plank (2011).

Ho2: There is no significant difference in the mean ratings of teachers' responses on the extent to which implementation of teachers' decisions serves as a correlate of teachers' job performance in junior secondary schools in the area of the study. The result of the study indicated that the null hypothesis was accepted which shows that there is no significant difference in the mean ratings of teachers' responses on the extent to which implementation of teachers' decisions serves as a correlate of teachers' job performance. This is proved by the critical 1.96 which is greater than the Z-calculated which is 0.12 . This is in line with Okunamiri and Uba-Mbibi (2011), and Carole (2012) who opined that the problem with Nigerian educational system is not on decision-making formulation but in the implementation of decision.

\section{Recommendations}

1. Principals of schools should be trained and retrained through workshops and seminars by experts to help them know the need to involvement of teachers in decision making.

2. Government of Abia State should direct the school principals to ensure that teachers' good decisions are implemented in their schools to enhance teachers' cooperation with the school policies and daily operations and to perform effectively.

3. Both Abia State government and general public should endeavour to provide adequate infrastructural facilities in schools so that teaching and learning will be interesting and fruitful.

4. The esteem of secondary school teachers should be adequately recognized by the school administrators just as their counterpart in other professions.

\section{References}

Ako S. (2011). Analysis of Teachers Job Satisfaction in Nigeria. Kaduna. Shamac Butter, K. (2012). Motivation and Personality. New York, Paper Raw. Benin City. Monose Amalgamates.

Carole. S. (2012). Improving Performance of the Nigerian Workers.

Federal Republic of Nigeria (2004). National Policy on Education, Federal Government Press. Lagos.

Mark, L. (2011). Introduction to Teachers' Education. Britain Taristock..

Perry, U. (2012). Management of Public Performance. The Way Forward. Britain Taristock..

Mba, O, (2011). A Hand Book of Educational Management in Nigerian Schools: Theory and Pry and Practice. Benin City. Monose Amalgamates.

Tanfox, S. (2010). Applied Human Relationship. New York Preaegers Publishers.

Uba-Mbibi, F.O. (2011). Handling Conflict and Confrontation in Organization in Abia State of Nigeria. Journal of Professional Secretarial and Office Administrators. NAPSSN Publishers, Nigeria. Volume 19. No 1.

Okunamiri, P.O. and Uba-Mbibi, F. O. (2011). Perceived Influence of Job Satisfaction on Teachers in Secondary Schools in Umuahia Education Zone of Abia State. Current Issues in Nigeria Education. A book of reading. Whytem publishers Nigeria. 